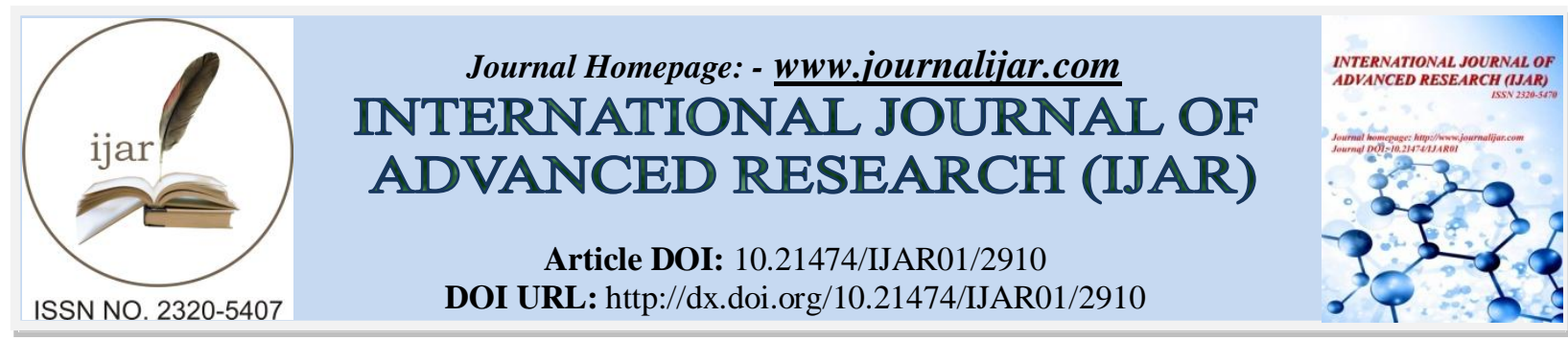

RESEARCH ARTICLE

\title{
SYSTEMIC ANTIOXIDANTS IN MANAGEMENT OF ORAL SUBMUCOUS FIBROSIS: A SYSTEMATIC REVIEW OF RANDOMISED CONTROL TRIALS AND META-ANALYSIS.
}

Dr. Kondajji Ramchandra Vijayalakshmi ${ }^{1},{ }^{*}$ Dr. Ankit Srivastava ${ }^{2}$ and Dr. Mubeen Khan ${ }^{3}$.

1. Associate Professor (M.D.S), Room No.1, Department of Oral Medicine \& Radiology, Govt. Dental College \& Research Institute, [Affiliated to Rajiv Gandhi University of Health Sciences (RGUHS)], Bangalore-560002.

2. Post Graduate Student, Room No.1, Department of Oral Medicine \& Radiology, Govt. Dental College \& Research Institute [Affiliated to Rajiv Gandhi University of Health Sciences (RGUHS)], Bangalore-560002.

3. Professor \& Head (M.D.S), Room No. 1, Department of Oral Medicine \& Radiology, Govt. Dental College \& Research Institute, [Affiliated to Rajiv Gandhi University of Health Sciences (RGUHS)], Bangalore-560002.

\section{Manuscript Info}

Manuscript History

Received: 28 November 2016

Final Accepted: 26 December 2016

Published: January 2017

Key words:-

Free radicals, medication therapy, management, Mouth opening.
Abstract

Introduction: Antioxidants relieve the signs and symptoms of oral submucous fibrosis by decreasing the load of free radicals.

Aim: The aim of this systematic review was to retrieve and analyse clinical studies investigating systemic antioxidants in the management of OSMF.

Material and method: Literature was searched in electronic search engines from 1995 to 2015. The identified titles / abstracts were independently screened according to set criteria for selection of abstracts. The full - text articles retrieved were assessed for eligibility and the eligible studies were assessed for qualitative and quantitative evidence. 9 full text articles were selected and assessed for eligibility. 6 full text articles were eligible for qualitative and quantitative analysis. Meta - analysis was done for mouth opening.

Results: The extracted data resulted in 207 subjects using systemic antioxidants. Meta - analysis of the combined data of the studies administering systemic antioxidants as a single entity or in combination with intralesional corticosteroids $(\mathrm{n}=121)$ as compared to other interventions $(\mathrm{n}=121)$ did not depict significant improvement in mouth opening (SMD $=-1.446 ; 95 \% \mathrm{CI}=-3.332$ to -0.439$)$ with significant test of heterogeneity $(\mathrm{p}=0.0001<0.05)$. Meta - analysis of the combined data of all the interventional groups $(n=207)$ and control groups $(n=203)$ which depicted that systemic antioxidants as a single entity or in combination with intralesional steroids significantly improve mouth opening v/s controls $(\mathrm{SMD}=-1.235 ; 95 \% \mathrm{CI}=-$ 2.263 to -0.206 ) with a significant test of heterogeneity (and $p=0.0001$ $<0.05)$.

Conclusion: Although the meta - analysis indicates that antioxidants appear to be effective in management of OSMF, the high degree of heterogeneity and limited amount of data in this systematic review and meta - analysis does not provide a credible evidence to support these observations. 
Copy Right, IJAR, 2016,. All rights reserved.

\section{Introduction:-}

Oral submucous fibrosis (OSMF) is a chronic, debilitating disease characterized by juxtaepithelial fibrosis of oral mucosa resulting in limitation of mouth opening and burning sensation.[1] Its etiopathogenesis is multifactorial with a high prevalence in areca nut chewers. OSMF is a potentially malignant disorder with a malignant transformation rate of 2.3 to $7.6 \%$.[2][3] The most common debilitating symptoms of OSMF are burning sensation in the mucosa and inability to open mouth which also has psychological and social implications for patients.

Management of OSMF aims to reduce the symptoms and prevent the risk of malignant transformation. The current protocol for the management of OSMF can be divided into 3 broad groups: pharmacological, physical and surgical modalities.[4]

Pharmacological management includes usage of Vitamins and Antioxidants, anti - inflammatory drugs (principally corticosteroids), proteolytic agents (such as hyaluronidase) and anti - cytokines. Antioxidants act through their anti inflammatory, anti - mutagenic and anti - carcinogenic properties. Moreover, Antioxidants stabilize and deactivate the free radicals which are induced by the ingredients of the betel nut. Various studies have shown that antioxidants are highly effective in controlling the signs and symptoms of OSMF and have been the mainstay of a conservative approach for management of OSMF.[4][5]

Several narrative and systematic reviews on management of OSMF have highlighted the beneficial role of various antioxidants like natural extracts, micronutrients, vitamins, nutritional supplements.[5][6][7] Nonetheless, no systematic review or meta - analysis has yet given evidence of efficacy of systemic Antioxidants in management of OSMF. Thus, this systematic review aimed to critically summarize and evaluate results of clinical studies investigating systemic antioxidants to improve signs and symptoms of OSMF.

Aim:-

To assess the effect of systemic antioxidants in the management of clinical signs and symptoms of OSMF by comparing them with each other and other treatment modalities through meta - analysis of retrieved data and to compare the effect of various systemic antioxidants used in the management of clinical signs and symptoms of OSMF

\section{Material and methods:- \\ Review design:-}

The present systematic review was carried out by three investigators with an aim to systematically retrieve and analyse clinical studies investigating antioxidants in the management of clinical signs and symptoms of OSMF. The $3^{\text {rd }}$ investigator performed an electronic search. Thus identified titles / abstracts through the search engines were independently screened by first and second investigators according to set inclusion and exclusion criteria for selection of abstracts. Full text articles of the selected abstracts were retrieved by the third investigator and further retrieval of titles / abstracts was done by cross - referencing of full - text articles. The full - text articles were assessed for eligibility by the first and second investigators and the selected studies are assessed for the quality of their reporting.

\section{Search strategy:-}

An electronic data base search was performed in PubMed and Science Direct for last 20 years from a time period of January 1995 to March 2015. The MESH keywords were ANTIOXIDANTS, MICRONUTRIENTS, VITAMINS, NUTRITIONAL SUPPLEMENTS combined with OSMF with Boolean term "AND”. A total of 1189 title / abstracts identified through the search engines and the 9 title / abstracts identified through manual search were independently screened according to set inclusion and exclusion criteria for selection of Titles / abstracts (Table.1). The investigators were not blinded to journal names or authors. Screening yielded total of 41 title / abstracts out of which 12 full text articles could be retrieved. 3 full text articles were excluded because of repetition. Finally 9 full text articles were selected and assessed for eligibility through PICO guidelines. Agreement concerning study inclusion or exclusion was achieved by thorough discussion among the investigators. Further 6 full - text articles were selected which fulfilled the PICO guidelines. These full - text articles are qualitatively analysed with consort 
guidelines 2010 as modified by Fricton et al. The extracted data was quantitatively assessed for the outcomes. (Flowchart - 1; showing the search strategy)

\section{2 assessment of eligibility (With PICO guidelines)[8]-}

The 9 full - text articles were evaluated with participants, interventions, comparators, outcomes (PICO) guidelines as follows-

\section{Participants-}

Studies with human participants, who were diagnosed as having OSMF clinically or histologically or both.

\section{Type of interventions-}

Systemic Antioxidants as a single entity or in combination, at any dosage and over any time period.

\section{Comparators (Control)-}

Negative (placebo treatment), positive (other intervention; i.e other treatment modalities or antioxidant administered in any other mode).

\section{Outcomes-}

The primary outcomes assessed were- maximal mouth opening, burning sensation, palpable fibrous bands, tongue movements. Secondary outcomes assessed were the adverse effects of the antioxidants used and Change or improvement of nutritional status by laboratory investigations and clinical evaluation.

\section{Data extraction and synthesis-}

Data of the 9 full - text articles was extracted and recorded in a format designed for this purpose. The data extracted from all the studies were combined and the subjects who were administered systemic antioxidants alone or in combination with other treatment modalities were considered into interventional group. Subjects who were administered placebo, intralesional corticosteroids or topical antioxidants were considered in control group.

The data of the 9 full - text articles were assessed for eligibility according to PICO guidelines. However, only 6 studies could be included in the systematic review after assessment of eligibility (Table.2). [9] [10] [11] [12] [13] [14] [15] [16] [17].

The extracted data resulted in 207 subjects using systemic antioxidants these subjects were considered to be in interventional group in the systematic review and meta - analysis. 203 subjects were considered in the control / comparator group. Out of which, 82 were included in the placebo group, 121 controls were in the other treatment modalities group like intralesional corticosteroids or topical antioxidants.

\section{Quality assessment of selected studies-}

The quality of reporting of RCTs was carried out by using the 2010 CONSORT criteria as modified by Fricton, et al. $1^{\text {st }}$ and $2^{\text {nd }}$ investigators independently evaluated the method of randomization and blinding using points $8,9,10,11$, 15, 16 of CONSORT guidelines 2010 as they are the indicators of risk of systemic bias (Table 3 showing the details). In case of disagreement between the investigators, differences were discussed and a decision was made by consensus. The overall score of the studies gave an average of 6.83 which varied from a minimum of six to a maximum of 8 (scoring shown in Table 4).[18]

\section{Statistical analysis:-}

The extracted data of the selected studies are tabulated. Meta - analysis could be achieved only for one primary outcome i.e mouth opening as the method of its assessment was uniform in all the included studies. Due to heterogeneity of data and methods of assessment the rest of the primary outcomes could not be taken for meta analysis. The primary measures of effect between treatment and control groups for mouth opening were calculated as the standardized mean differences (SMDs) with a 95\% confidence interval. A random and fixed effects model was used to calculate a pooled estimate effect. Cochrane's Q test, a statistic based on the chi - squared test was used to assess the existence of heterogeneity among the interventional and control groups for mouth opening.

\section{Results:-}

Study characteristics:-

The electronic searches yielded a total of 1889 articles and manual search yielded total of 9 articles. Following a meticulous search strategy according to prisma guidelines (FIGURE.1), finally 9 full text articles were selected and assessed for eligibility through PICO guidelines. Further 6 full - text articles were selected which fulfilled the PICO 
guidelines. These full - text articles were qualitatively analysed with CONSORT guidelines 2010 as modified by Fricton et al. The extracted data was quantitatively assessed for the outcomes. The data analysis yielded complete information for only one of our primary outcomes i.e mouth opening. Meta - analysis could be achieved only for mouth opening as the methodology used for its assessment was same in all the included studies. All the other primary outcomes could not be taken for meta - analysis due to heterogeneous in complete data and different methodology used for their assessment.

\section{Characteristics of outcomes:- Mouth opening:-}

All the 6 included studies assessed change in mouth opening as one of their treatment outcomes. All the studies measured mouth opening using interincisal distance in dentulous patients and for edentulous patients, the opening between the upper and lower ridges was recorded (Table.2).

\section{Other primary outcomes:-}

Burning sensation was assessed by 5 of the included studies except from Patil et al 2014. This outcome was assessed by the 5 studies subjectively using different scales. Changes in palpable fibrous bands was assessed by Kumar et al.[9]. Karemore et al, Salvem et al, Patil et al 2014, Patil et al 2015 did not record changes in palpable fibrous bands. Changes in tongue movements was recorded by Kumar et al, Sudarshan et al and Patil et al 2014 however Karemore et al, Selvam et al and Patil et al 2015 did not record changes in tongue protrusion.(Table.2)

\section{Adverse reactions:-}

There were no side effects or intolerance to lycopene and other antioxidants reported by Kumar et al, Karemore et al, Selvam et al during the treatment period and follow - up. However, Karemore et al reported one case which showed ulceration and burning sensation of oral cavity for a period of one week during follow - up.

Patil et al 2014, reported mild abdominal discomfort due to Oxitard in 8 patients. Patil et al 2015 did not report any side effects of the antioxidants used.

\section{Meta analysis:-}

Metaanalysis was done for only one of our primary outcome i.e mouth opening. Forest plots were drawn for systemic antioxidants vs placebo, systemic antioxidants vs other controls (other treatment modalities) and systemic antioxidants vs controls (combining both placebo and other treatment modalities) using the standard mean deviations (SMDs) and pooled fixed and random overall effects were tabulated.

Patients administered $16 \mathrm{mg}$ lycopene capsules (Kumar et al, Karemore et al) and $16 \mathrm{mg}$ lycopene capsules with intralesional injection of betamethasone $8 \mathrm{mg}$ daily (Kumar et al) v/s placebo depicted significantly improved mouth opening ( $\mathrm{SMD}=-0.959 ; 95 \% \mathrm{CI}=-1.284$ to -0.635 ; for fixed effects and $\mathrm{SMD}=-0.941 ; 95 \% \mathrm{CI}=-1.309$ to -0.574 ; for random effects). Q test of heterogeneity was $2.4608, \mathrm{df}=2$ and $\mathrm{p}$ value of $0.2922>0.05$ which was not significant.(Fig.2)

Patients administered oral lycopene (lycostar) $16 \mathrm{mg}$ O.D with bi-weekly intralesional dexamethasone \& hyaluronidase and oral antioxidant capsules (Multivitamin A $-\mathrm{Z}$ soft capsules) O.D with bi-weekly intralesional Dexamethasone \& Hyaluronidase (interventional group) v/s bi-weekly intralesional Dexamethasone \& Hyaluronidase (control group); (Salvem et al). Patients administered 2 oxitard capsules t.i.d (interventional group) v/s $5 \mathrm{mg}$ aloevera gel to be applied topically t.i.d. (control group); (Patil et al 2014). Patients administered $500 \mathrm{mg}$ spirulina capsules b.i.d. (interventional group) v/s $5 \mathrm{mg}$ aloevera gel topically t.i.d. (control group); (Patil et al 2015). Patients administered aloevera gel $5 \mathrm{mg}$ on each side of buccal mucosa thrice daily for 3 months. (control group) v/s antioxidant capsules twice daily for 3 months (interventional group); (Sudarshan et al) did not significantly improve mouth opening considering the random effects model ( $\mathrm{SMD}=-1.516 ; 95 \% \mathrm{CI}=-1.853$ to 1.179); for fixed effects and $\mathrm{SMD}=-1.446 ; 95 \% \mathrm{CI}=-3.332$ to -0.439 ; for random effects). $\mathrm{Q}$ test of heterogeneity was $122.9207, \mathrm{df}=4$ with a significant $\mathrm{p}$ value of 0.0001 . Hence, here emphasis should be placed on random effects model as test for heterogeneity is significant.(Fig.2)

A third forest plot was drawn combining all the interventional groups and control groups (placebo \& other treatment modalities) which depicted that systemic antioxidants as a single entity or in combination with other treatment modalities i.e intralesional steroids significantly improve mouth opening v/s controls i.e topical antioxidants and intralesional steroids considering the random effects model. ( $\mathrm{SMD}=-1.226 ; 95 \% \mathrm{CI}=-1.459$ to -0.993 ); for fixed 
effects and SMD $=-1.235 ; 95 \% \mathrm{CI}=-2.263$ to -0.206 ; for random effects). Q test of heterogeneity was 130.8958, $\mathrm{df}$ $=7$ with a significant $\mathrm{p}$ value of 0.0001 . Hence, here emphasis should be placed on random effects model as test for heterogeneity is significant. (Fig.2)

\section{Discussion:-}

Antioxidants provide a non - invasive conservative approach for management of OSMF. Various studies have proved that antioxidants when used as a standard or adjunct are effective in controlling the signs and symptoms of OSMF. This systematic review aimed to assess the evidence of systemic antioxidants in management of signs and symptoms of OSMF and to compare the systemic antioxidants with other treatment modalities in improving the signs and symptoms of OSMF. This systematic review included only randomized controlled trials, as non randomized trials tend to show frequent "false - positive" results than randomized trials.

The primary outcomes assessed in this review were based on the signs and symptoms of OSMF. Mouth opening was measured in all the 6 studies as inter - incisal distance. Hence a Meta - analysis was carried out to assess the evidence of effectiveness systemic antioxidants in improving the mouth opening.

The systemic anti - oxidants reported in the RCTs of this systematic review are lycopene, spirulina, oxitard and antioxidant capsules. 3 Out of 6 RCTs administered lycopene in one of their interventional group. The Meta - analysis of lycopene as a single component or in combination with intralesional corticosteroids suggests an evidence that lycopene when given in a dosage of $16 \mathrm{mg}$ twice daily for two months as a single entity or in combination with intralesional corticosteroids may be effective in improving the mouth opening in OSMF patients as compared with placebo $(\mathrm{SMD}=-0.959 ; 95 \% \mathrm{CI}=-1.284$ to -0.635$)$.

Metaanalysis of the combined data of the studies administering systemic antioxidants as a single entity or in combination with intralesional corticosteroids $(n=121)$ as compared to other interventions $(n=121)$ i.e topical antioxidants and intralesional corticosteroids (Salvem et al, Patil et al 2014, Pati et al 2015, Sudarshan et al) does not depict significant improvement in mouth opening ( $\mathrm{SMD}=-1.446 ; 95 \% \mathrm{CI}=-3.332$ to -0.439 ). This attributes to lack of credible evidence and high variability in between the studies as depicted significant test of heterogeneity $(\mathrm{p}=$ $0.0001<0.05)$ to estimate the effect of intervention. However, it can be inferred that systemic antioxidants as a single entity or in combination with intralesional corticosteroids does not seem to be better than other treatment modalities i.e intralesional corticosteroids and topical antioxidants in improving mouth opening patients with OSMF.

Meta-analysis of the combined data of all the interventional groups $(n=207)$ and control groups $(n=203$; placebo $\&$ other treatment modalities) which depicted that systemic antioxidants as a single entity or in combination with other treatment modalities i.e intralesional steroids significantly improve mouth opening v/s controls i.e topical antioxidants and intralesional steroids ( $\mathrm{SMD}=-1.235 ; 95 \% \mathrm{CI}=-2.263$ to -0.206$)$. However, this data also depicted high variability in between the studies as depicted by significant test of heterogeneity (and $p=0.0001<0.05$ ).

\section{Limitations:-}

The meta-analysis and systematic review reported here combines data across studies in order to estimate treatment effects with more precision than is possible in a single study. The main limitation of this meta - analysis, as with any overview is that the antioxidant used and the outcome definitions are not the same across studies. Only one primary outcome could be assessed i.e mouth opening, rest of primary and secondary outcomes could not be assessed due to lack of consensus among researchers invalidation of other signs and symptoms of OSMF. Although, only two studies mention about the adverse effects of the systemic antioxidant used. This leads us to an observation that systemic antioxidants are relatively safe for the treatment of OSMF. Moreover, the lack of assessment of nutritional status by laboratory investigation or clinical evaluation further highlights the lack of clear markers in serum and saliva which can reliably estimate the overall status of the subjects suffering from OSMF.

At the study and review level our review did not include any grey literature and studies published in other languages were not considered in the review. Only 12 full - text article could be retrieved due to constrained resources available to the investigators. Although, randomization of the selected studies was adequate the quality of randomization varied and none of the studies could be given high scores according to CONSORT guidelines as modified by Friction et al. 


\section{Conclusions:-}

Implications for practice:-

Although the investigators in all the trials concluded that the results indicated that antioxidants were safe, appeared to be effective in reducing symptoms and might prove beneficial in the therapeutic management of oral submucous fibrosis, the uncertain reliability of the limited amount of available data would not appear to support these contentions. Moreover, the meta-analysis carried out for mouth opening suggests that systemic antioxidants are not as effective when compared with other interventions but it does indicate a certain beneficial role of systemic antioxidants being used as an adjuvant with other medical intervention. Additionally other antioxidants like Oxitard and Spirulina have proved to be effective in alleviating the signs and symptoms of OSMF.

\section{Implications for research:-}

OSMF has proven to be a significant global burden, especially in the South Asian countries where prevalence of this debilitating disease is relatively more. But treatment of OSMF has been clearly inadequate owing to its multifactorial pathogenesis and evaluation of the merits and disadvantages of individual drugs has been difficult because of empirical nature of the approach.

This systematic review opines that future research trials should be reported strictly adhering to the CONSORT guideline to ensure high quality research especially in terms of randomization and blinding of the subjects for better results. Further the effect of drug on progression of the OSMF can be assessed by using various classifications present in literature based on signs and symptoms of OSMF. However, this systematic review stresses the need of consensus among investigators for the various clinical criteria used to assess OSMF so that significant evidence of a particular treatment modality like antioxidant could be achieved in future review designs.

\section{Conflicts of interest - NONE}

Table 1:-Showing inclusion and exclusion criteria used for screening of title / abstracts

INCLUSION CRITERIA-

1. Randomised clinical trials which mention the use of antioxidants for management of OSMF on human subjects.

2. Randomised clinical trials in the management of OSMF which include a group intervened with systemic antioxidants by random allocation.

3. Randomised clinical trials in which effect of systemic antioxidants on signs and symptoms of OSMF could be clearly / separately identified.

EXCLUSION CRITERIA-

1. Publications written in languages other than English.

2. $\quad$ Review articles on management of OSMF.

3. Non-randomised studies on management of OSMF. 
Table 2:- Showing assessment of 9 full text articles for eligibility according to PICO guidelines with the details of data extraction.

\begin{tabular}{|c|c|c|c|c|c|c|c|}
\hline $\begin{array}{l}\text { Author } \\
\text { s \& } \\
\text { Year }\end{array}$ & $\begin{array}{l}\text { Study type \& } \\
\text { participants }\end{array}$ & $\begin{array}{l}\text { Interventio } \\
\text { ns }\end{array}$ & $\begin{array}{l}\text { Systemic } \\
\text { antioxidant } \\
\text { used }\end{array}$ & $\begin{array}{l}\text { Interventional } \\
\text { period / follow } \\
\text { up }\end{array}$ & Outcomes & $\begin{array}{l}\text { Assessm } \\
\text { ent of } \\
\text { eligibilit } \\
y\end{array}$ & $\begin{array}{l}\text { Reasons for } \\
\text { exclusion }\end{array}$ \\
\hline $\begin{array}{l}\text { Kumar } \\
\text { et al, } \\
2007\end{array}$ & $\begin{array}{l}\text { Randomise } \\
\text { control trial. } \\
\text { GroupA }=21 \\
\text { GroupB }=19 \\
\text { GroupC }=18\end{array}$ & $\begin{array}{l}\text { Gr A:Oral } \\
\text { lycopene } \\
16 \mathrm{mg} \text { b.i.d. } \\
\text { Gr B: Oral } \\
\text { lycopene } \\
16 \mathrm{mg} \text { daily } \\
+ \\
\text { intralesiona } \\
1 \text { injection } \\
\text { betamethas } \\
\text { one } 8 \mathrm{mg} \\
\text { twice } \\
\text { weekly. }\end{array}$ & LYCOPENE & $\begin{array}{l}2 \text { months/ } \\
\text { weekly } \\
\text { assessment. } \\
\text { Follow-up at } 3^{\text {rd }} \\
\text { and } 6^{\text {th }} \text { month } \\
\text { post treatment }\end{array}$ & $\begin{array}{l}\text { Mouth opening, } \\
\text { Tongue } \\
\text { protrusion, } \\
\text { Palpable fibrous } \\
\text { bands in the } \\
\text { buccal mucosa, } \\
\text { Burning } \\
\text { sensation. }\end{array}$ & $\begin{array}{l}\text { Included } \\
\text { for } \\
\text { review }\end{array}$ & \\
\hline $\begin{array}{l}\text { Rao et } \\
\text { al, } \\
2010\end{array}$ & $\begin{array}{l}\text { Randomised } \\
\text { Case control } \\
\text { study Group } \\
1=9 \\
\text { Group } 2=9\end{array}$ & $\begin{array}{l}\text { Group 1: } \\
\text { intralesiona } \\
1 \\
\text { betamethas } \\
\text { one } 1 \mathrm{ml} \\
\text { with } \\
\text { hyaluronida } \\
\text { se } 1500 \mathrm{IU} \\
\text { weekly } \\
\text { once for } 12 \\
\text { weeks } \quad \\
\text { alpha lipoic } \\
\text { acid } \\
\text { administere } \\
\text { d orally OD } \\
\text { for } \\
\text { months } \\
\text { Group } 2 \text { : } \\
\text { intralesiona } \\
1 \\
\text { betamethas } \\
\text { one } 1 \text { ml } \\
\text { with } \\
\text { hyaluronida } \\
\text { se } 1500 \mathrm{IU} \\
\text { weekly } \\
\text { once for } 12 \\
\text { weeks }\end{array}$ & $\begin{array}{l}\text { ALPHA } \\
\text { LIPOIC } \\
\text { ACID }\end{array}$ & $\begin{array}{l}6 \\
\text { months/fortnigh } \\
\text { tly }\end{array}$ & $\begin{array}{l}\text { Mouth opening, } \\
\text { Burning } \\
\text { sensation, } \\
\text { Post treatment } \\
\text { biopsy. }\end{array}$ & $\begin{array}{l}\text { Exclude } \\
\text { d }\end{array}$ & $\begin{array}{l}\text { 1. Cas } \\
\text { e-control } \\
\text { study. } \\
\text { 2. Outcome } \\
\text { s not } \\
\text { mentione } \\
\text { d clearly. }\end{array}$ \\
\hline $\begin{array}{l}\text { Karem } \\
\text { ore et } \\
\text { al, } \\
2012\end{array}$ & $\begin{array}{l}\text { Randomised } \\
\text { control trial } \\
\text { Lycopenegro } \\
\text { up=46 } \\
\text { Placebo } \\
\text { group=46 }\end{array}$ & $\begin{array}{l}\text { Lycopene } \\
\text { gr. = } 8 \mathrm{mg} \\
\text { oral } \\
\text { Lycored } \\
\text { capsules } \\
\text { orally bid } \\
\text { for } 3 \\
\text { months } \\
\text { Placebo gr. } \\
=\text { placebo } \\
\text { twice a day }\end{array}$ & LYCOPENE & $\begin{array}{l}2 \\
\text { months/fortnigh } \\
\text { tly } \\
2 \text { months } \\
\text { follow-up post- } \\
\text { treatment. }\end{array}$ & $\begin{array}{l}\text { Mouth opening } \\
\text { Burning } \\
\text { sensation } \\
\text { Erythematous } \\
\text { areas } \\
\text { ulcerations } \\
\text { erosions }\end{array}$ & $\begin{array}{l}\text { Included } \\
\text { for } \\
\text { review }\end{array}$ & \\
\hline
\end{tabular}




\begin{tabular}{|c|c|c|c|c|c|c|c|}
\hline & & orally & & & & & \\
\hline $\begin{array}{l}\text { Sudars } \\
\text { han et } \\
\text { al, } \\
2012\end{array}$ & $\begin{array}{l}\text { Randomised } \\
\text { control trial } \\
\text { GroupA }=10 \\
\text { GroupB }=10\end{array}$ & $\begin{array}{l}\text { Gr A- } \\
\text { topical } \\
\text { aloevera } \\
\text { gel / tid for } \\
3 \text { months. } \\
\text { Gr B- } \\
\text { antioxidant } \\
\text { capsules / } \\
\text { bid for } 3 \\
\text { months. }\end{array}$ & $\begin{array}{l}\text { ANTIOXID } \\
\text { ANT } \\
\text { CAPSULES }\end{array}$ & 3months & $\begin{array}{l}\text { Mouth opening } \\
\text { Burning } \\
\text { sensation } \\
\text { Cheek } \\
\text { flexibility } \\
\text { Tongue } \\
\text { protrusion }\end{array}$ & $\begin{array}{l}\text { Included } \\
\text { for } \\
\text { review }\end{array}$ & \\
\hline $\begin{array}{l}\text { Shetty } \\
\text { et al, } \\
2012\end{array}$ & $\begin{array}{l}\text { Interventiona } \\
1 \text { study } \\
\text { GroupA }=20 \\
\text { GroupB }=20\end{array}$ & $\begin{array}{l}\text { Gr A- } \\
\text { spirulina } \\
500 \mathrm{mg} \text { bid } \\
\text { for } \\
\text { months }+ \\
\text { betamethas } \\
\text { one } \\
\text { intralesiona } \\
14 \mathrm{mg} / \mathrm{ml} \\
\text { bi-weekly. } \\
\text { Gr B- } \\
\text { Placebo bid } \\
\text { for } 3 \\
\text { months }+ \\
\text { betamethas } \\
\text { one intralesiona } \\
14 \text { mg / ml } \\
\text { bi-weekly }\end{array}$ & SPIRULINA & $\begin{array}{l}\text { 3months/twice a } \\
\text { month. }\end{array}$ & $\begin{array}{l}\text { Mouth opening } \\
\text { Burning } \\
\text { sensation }\end{array}$ & $\begin{array}{l}\text { Exclude } \\
\text { d }\end{array}$ & $\begin{array}{l}\text { 1. Random } \\
\text { isation } \\
\text { and } \\
\text { blinding } \\
\text { not } \\
\text { mention } \\
\text { ed } \\
\text { clearly. }\end{array}$ \\
\hline $\begin{array}{l}\text { Salve } \\
\mathrm{m} \text { et } \\
\mathrm{al}, \\
2013\end{array}$ & $\begin{array}{l}\text { Randomised } \\
\text { control trial } \\
\text { GroupA=15 } \\
\text { Group } B=15 \\
\text { Group } C=15\end{array}$ & $\begin{array}{l}\text { Gr A: Oral } \\
\text { lycopene } \\
\text { (lycostar) } \\
16 \text { mg O.D } \\
+\quad \text { bi- } \\
\text { weekly } \\
\text { intralesiona } \\
1 \text { dexamethas } \\
\text { one \& } \\
\text { hyaluronida } \\
\text { se. } \\
\text { Gr B: oral } \\
\text { antioxidant } \\
\text { capsules } \\
\text { (Multivita } \\
\text { min A }- \text { Z } \\
\text { soft } \\
\text { capsules) } \\
\text { O.D + bi- } \\
\text { weekly } \\
\text { intralesiona } \\
1 \\
\text { Dexametha } \\
\text { sone \& } \\
\text { Hyaluronid }\end{array}$ & $\begin{array}{l}\text { LYCOPENE } \\
\text { MULTIVIT } \\
\text { AMINS }\end{array}$ & $\begin{array}{l}6 \text { week / weekly } \\
\text { intervals }\end{array}$ & $\begin{array}{l}\text { Mouth opening. } \\
\text { Burning } \\
\text { sensation. }\end{array}$ & $\begin{array}{l}\text { Included } \\
\text { for } \\
\text { review }\end{array}$ & \\
\hline
\end{tabular}




\begin{tabular}{|c|c|c|c|c|c|c|c|}
\hline & & $\begin{array}{l}\text { ase. } \\
\text { Gr C } \\
(\mathrm{n}=15): \text { bi- } \\
\text { weekly } \\
\text { intralesiona } \\
\text { l } \\
\text { Dexametha } \\
\text { sone \& } \\
\text { Hyaluronid } \\
\text { ase. }\end{array}$ & & & & & \\
\hline $\begin{array}{l}\text { Alam } \\
\text { et al, } \\
2013\end{array}$ & $\begin{array}{l}\text { Randomised } \\
\text { control trial } \\
\text { Medicinalgro } \\
\text { up=30 } \\
\text { Surgical } \\
\text { group }=30\end{array}$ & $\begin{array}{l}\text { All } \\
\text { patients- } \\
\text { Lycostar } \\
\text { capsules } \\
\text { bid } \\
\text { Capsule } \\
\text { Becosules - } \\
\text { Z od during } \\
\text { the } \\
\text { treatment } \\
\text { and upto } 6 \\
\text { month post- } \\
\text { treatment }+ \\
\text { physiothera } \\
\text { py for } \\
\text { mouth } \\
\text { opening 4-5 } \\
\text { times / day } \\
\text { Medicinal } \\
\text { group-: } \\
\text { submucosal } \\
\text { injections } \\
\text { twice/ week } \\
\text { of } \\
\text { hyaluronida } \\
\text { se (1500 } \\
\text { IU) for the } \\
\text { first } \\
\text { weeks. } \\
\text { Followed } \\
\text { by } \\
\text { submucosal } \\
\text { injection } \\
\text { twice/week } \\
\text { of } \\
\text { hyaluronida } \\
\text { se (1500 } \\
\text { IU) \& 4 mg } \\
\text { for the next } \\
7 \text { weeks. } \\
\text { Surgical } \\
\text { group- } \\
\text { surgical } \\
\text { excision of } \\
\text { fibrotic } \\
\text { Eands. }\end{array}$ & $\begin{array}{l}\text { LYCOPENE } \\
\text { MULTIVIT } \\
\text { AMINS }\end{array}$ & $\begin{array}{ll}\text { NOT } & \text { SAME } \\
\text { FOR } & \text { EACH } \\
\text { GROUP } & \end{array}$ & $\begin{array}{l}\text { Mouth opening } \\
\text { Burning } \\
\text { sensation } \\
\text { Elasticity of } \\
\text { buccal mucosa }\end{array}$ & $\begin{array}{l}\text { EXCLU } \\
\text { DED }\end{array}$ & $\begin{array}{l}\text { 1. Mul } \\
\text { tiple } \\
\text { antioxidants } \\
\text { used in both } \\
\text { interventional } \\
\text { and control } \\
\text { group. } \\
2 . \quad \text { Effe } \\
\text { ct of each } \\
\text { antioxidant } \\
\text { not } \\
\text { mentioned } \\
\text { clearly. }\end{array}$ \\
\hline
\end{tabular}




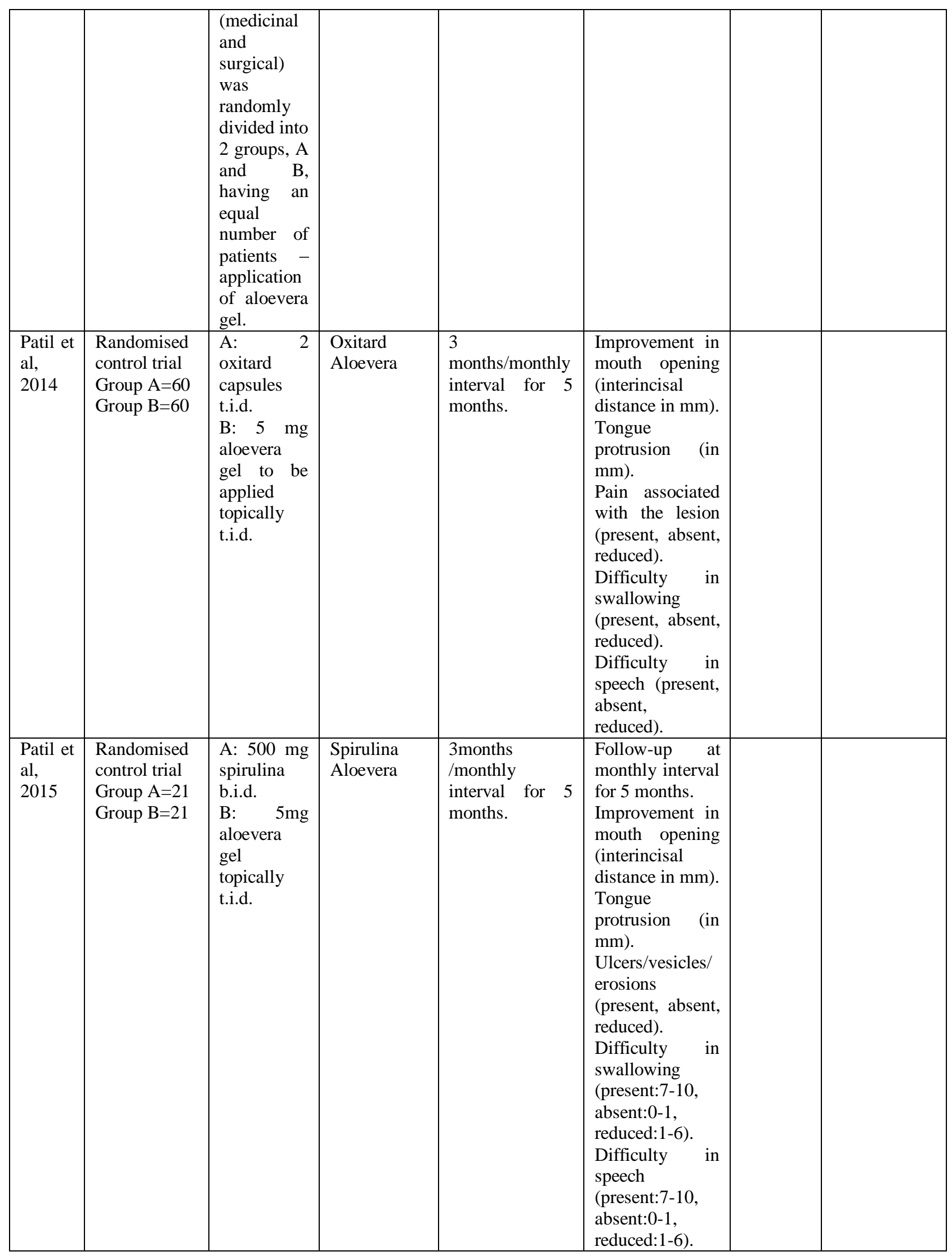


Table 3:- Showing qualitative assessment of randomized control studies according to CONSORT guidelines.

RISK OF BIAS-

\begin{tabular}{|c|c|c|c|c|c|c|}
\hline $\begin{array}{l}\text { CONSORT } \\
\text { CRITERIAS } \\
\text { ASSESSED }\end{array}$ & $\begin{array}{l}\text { Kumar et al, } \\
2007\end{array}$ & $\begin{array}{l}\text { Karemore et al, } \\
2012\end{array}$ & $\begin{array}{l}\text { Sudarshan et } \\
\text { al, } 2012\end{array}$ & $\begin{array}{l}\text { Salvem et al, } \\
2013\end{array}$ & $\begin{array}{l}\text { Patil et al, } \\
2014\end{array}$ & $\begin{array}{l}\text { Patil et al, } \\
2015\end{array}$ \\
\hline $\begin{array}{l}\text { Randomisation } \\
\text { sequence } \\
\text { generation (point } \\
\text { 8a consort } \\
\text { guidelines) }\end{array}$ & Not specified & Not specified & Not specified & Not specified & Not specified & Not specified \\
\hline $\begin{array}{l}\text { Type of } \\
\text { randomisation; } \\
\text { (point 8b consort } \\
\text { guidelines) }\end{array}$ & $\begin{array}{l}\text { Randomised; } \\
\text { double } \\
\text { blinded. }\end{array}$ & $\begin{array}{l}\text { Randomised; } \\
\text { single blind }\end{array}$ & $\begin{array}{l}\text { Randomised; } \\
\text { single blind. }\end{array}$ & $\begin{array}{l}\text { Randomised; } \\
\text { blinding not } \\
\text { mentioned }\end{array}$ & $\begin{array}{l}\text { Randomised; } \\
\text { single blind. }\end{array}$ & $\begin{array}{l}\text { Randomised; } \\
\text { blinding not } \\
\text { specified. }\end{array}$ \\
\hline $\begin{array}{l}\text { Randomisation / } \\
\text { allocation (point } 9 \\
\text { consort } \\
\text { guidelines) }\end{array}$ & Not specified & Not specified & Not specified & Not specified & Not specified & Not specified \\
\hline $\begin{array}{l}\text { Randomisation } \\
\text { implementation } \\
\text { (point } 10 \text { consort } \\
\text { guidelines) }\end{array}$ & $\begin{array}{l}1^{\text {st }} \text { Investigator } \\
\text { categorised } \\
\text { the pt. to } \\
\text { different } \\
\text { interventions. } \\
2^{\text {nd }} \\
\text { investigator } \\
\text { recorded } \\
\text { variables. }\end{array}$ & Not specified & Not specified & Not specified & Not specified & Not specified \\
\hline $\begin{array}{l}\text { Blinding } \\
\text { (point 11a consort } \\
\text { guidelines) }\end{array}$ & $\begin{array}{l}\text { Participants } \\
\text { and } \\
\text { investigators } \\
\text { were blinded }\end{array}$ & $\begin{array}{l}\text { Participants } \\
\text { were blinded }\end{array}$ & $\begin{array}{l}\text { Participants } \\
\text { were blinded }\end{array}$ & Not specified & Not specified & Not specified \\
\hline $\begin{array}{l}\text { Blinding (point } \\
11 \mathrm{~b} \text { consort } \\
\text { guidelines) } \\
\text { method of supply } \\
\text { of intervening } \\
\text { agent. }\end{array}$ & $\begin{array}{l}\text { Placebo } \\
\text { supplied was } \\
\text { manufactured } \\
\text { as bottled } \\
\text { lycored } \\
\text { capsules. }\end{array}$ & $\begin{array}{l}\text { Not specified } \\
\text { clearly }\end{array}$ & $\begin{array}{l}\text { Placebo not } \\
\text { used }\end{array}$ & $\begin{array}{l}\text { Placebo not } \\
\text { used }\end{array}$ & $\begin{array}{l}\text { Placebo not } \\
\text { used }\end{array}$ & $\begin{array}{l}\text { Placebo not } \\
\text { used }\end{array}$ \\
\hline $\begin{array}{l}\text { Baseline data } \\
\text { (point } 15 \text { consort } \\
\text { guidelines) }\end{array}$ & $\begin{array}{lr}\text { No. } & \text { of } \\
\text { subjects in } \\
\text { different age } \\
\text { group shown. }\end{array}$ & $\begin{array}{l}\text { Tables for Age } \\
\text { wise \& sex } \\
\text { distribution of } \\
\text { subjects with } \\
\text { baseline clinical } \\
\text { characteristics } \\
\text { shown }\end{array}$ & $\begin{array}{l}\text { Table of } \\
\text { changes of } \\
\text { baseline data } \\
\text { to follow-up } \\
\text { visits shown. }\end{array}$ & $\begin{array}{l}\text { Table } \\
\text { showing age } \\
\text { distribution } \\
\text { of subjects } \\
\text { shown. }\end{array}$ & $\begin{array}{l}\text { Table for } \\
\text { baseline } \\
\text { demographic } \\
\text { data NOT } \\
\text { given. }\end{array}$ & $\begin{array}{l}\text { Table for } \\
\text { baseline } \\
\text { demographic } \\
\text { data NOT } \\
\text { given. }\end{array}$ \\
\hline $\begin{array}{l}\text { Numbers of } \\
\text { participants } \\
\text { analysed. (point } \\
16 \quad \text { consort } \\
\text { guidelines) }\end{array}$ & $\begin{array}{l}\text { Specified } \\
(\mathrm{n}=58)\end{array}$ & Specified $(n=92)$ & $\begin{array}{l}\text { Specified } \\
(\mathrm{n}=20)\end{array}$ & $\begin{array}{l}\text { Specified } \\
(\mathrm{n}=45)\end{array}$ & $\begin{array}{l}\text { Specified } \\
(\mathrm{n}=120)\end{array}$ & $\begin{array}{l}\text { Specified } \\
(\mathrm{n}=42)\end{array}$ \\
\hline
\end{tabular}

Table 4:- Quality assessment using CONSORT criteria according to Fricton et al.

\begin{tabular}{|l|l|l|}
\hline & AUTHOR & SCORE \\
\hline 1 & Kumar et al, 2007 & 8 \\
\hline 2 & Karemore et al, 2012 & 8 \\
\hline 3 & Sudarshan et al, 2012 & 6 \\
\hline 4 & Salvem et al, 2013 & 6 \\
\hline 5 & Patil et al, 2014 & 7 \\
\hline 6 & Patil et al, 2015 & 7 \\
\hline
\end{tabular}


Figure1:- Flow chart showing search strategy for the systematic review-

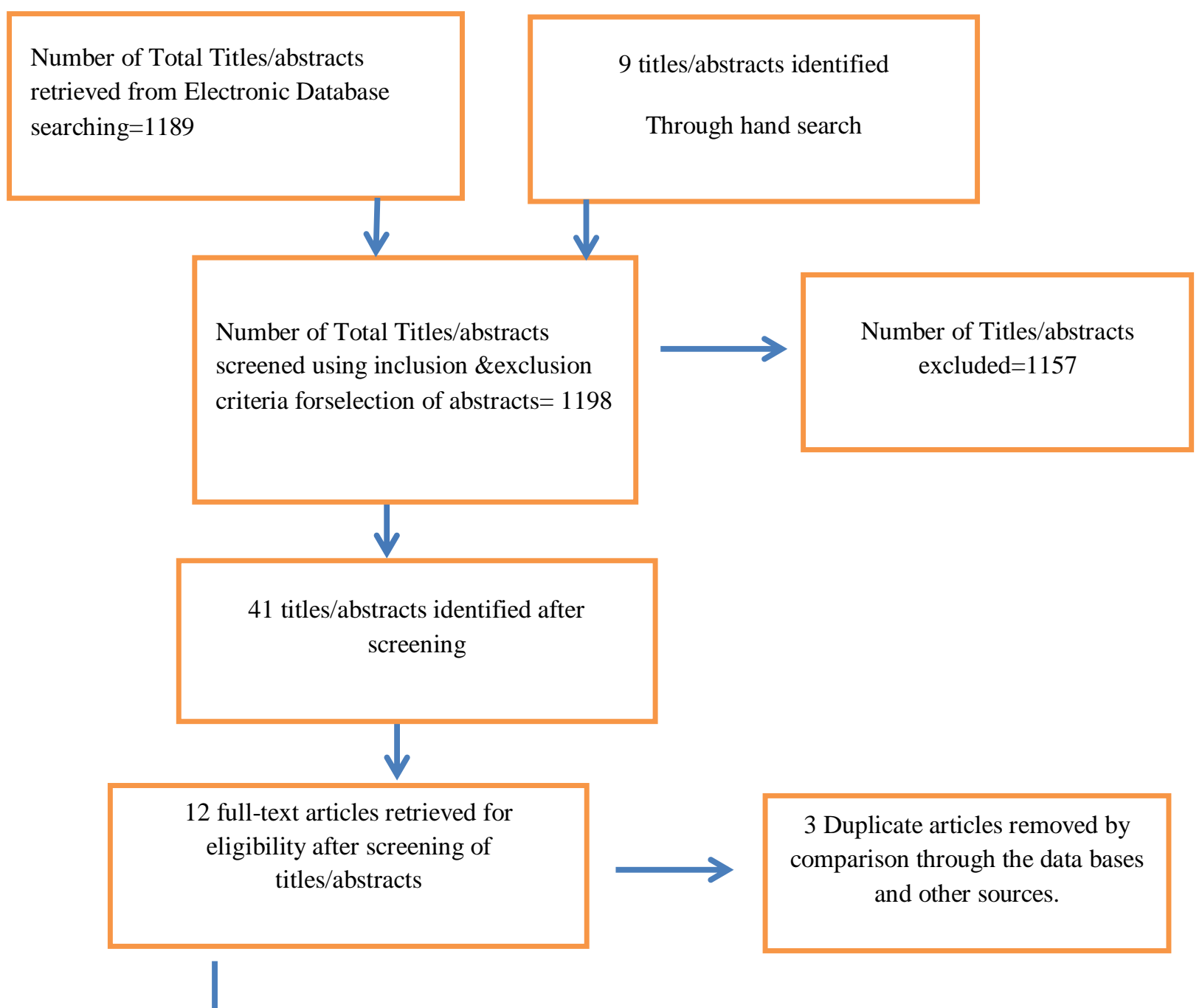

Full text articles retrieved and assessed for eligibility $n=9$

$(\mathrm{n}=8 ;$ database, $\mathrm{n}=1 ;$ other sources $)$
Eligibility assessment by PICO guidelines

\section{Excluded studies}

1. Rao et al, 2010 - Case control study, Outcomes not mentioned clearly

2. Shetty et al, 2012 - Randomization and blinding not mentioned clearly

3. Alam et al, 2013 - Multiple antioxidants used, Effect of each antioxidant not mentioned clearly

6 studies included in the systematic review and meta-analysis. 
Figure 2. Showing meta - analysis for mouth opening.

Comparison Standardized Mean Difference between Intervention and Placebo group

Test for heterogeneity

$\mathrm{Q}=2.4608$

$\mathrm{DF}=2$

Significance level, $\mathrm{P}=0.2922$

Comparison of Standarized Mean difference between Intervention and other Control Group

\begin{tabular}{|l|l|}
\hline Study & \\
\hline salvem et al & \\
\hline salvem et al & \\
patil,2014 & \\
patil,2015 & \\
\hline $\begin{array}{l}\text { sudarshan et } \\
\text { al }\end{array}$ & \\
\hline $\begin{array}{l}\text { Total (fixed } \\
\text { effects) }\end{array}$ & \\
\hline $\begin{array}{l}\text { Total } \\
\text { (random } \\
\text { effects) }\end{array}$ & \\
\hline
\end{tabular}

Test for heterogeneity

$\mathrm{Q}=122.9207$

$\mathrm{DF}=4$

Significance level, $\mathrm{P}<0.0001$

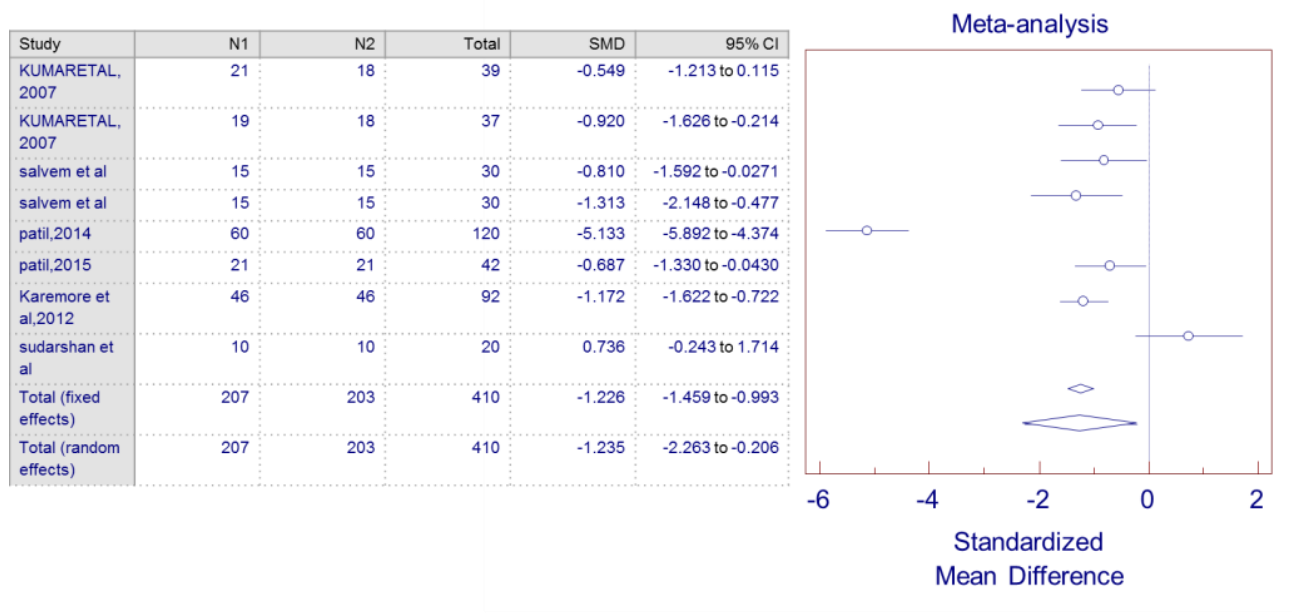


Test for heterogeneity

$\mathrm{Q}=130.8958$

$\mathrm{DF}=7$

Significance level, $\mathrm{P}<0.0001$

\section{References:-}

1. Rajalalitha P, Vali S. Molecular pathogenesis of oral submucous fibrosis - a collagen metabolic disorder. J Oral Pathol Med 2005;34:321-8.

2. Pindborg J J, Murti P R, Bhonsle R B, Gupta P C et al. Oral submucous fibrosis as a precancerous condition. Scand J Dent Res 1984;92:224-9.

3. Mathew A L, Pai K M, Sholapurkar A A et al. The prevalence of oral mucosal lesions in patients visiting a dental school in Southern India. Indian J Dent Res 2008;19:99-03.

4. G. Arakeri, P.A. Brennan. Oral submucous fibrosis: an overview of the aetiology, pathogenesis, classification, and principles of management. British Journal of Oral and Maxillofacial Surgery 2013;51:587-93.

5. Kerr AR, Warnakulasuriya S, Mighell A J et al. A systematic review of medical interventions for oral submucous fibrosis and future research opportunities. Oral Dis 2011;17:42-57

6. Lai D R, Chen H R, Lin L M et al. Clinical evaluation of different treatment methods for oral submucous fibrosis. A 10 - year experience with 150 cases. J Oral Pathol Med 1995;24:402-6.

7. Borle R M, Borle S R et al. Management of oral submucous fibrosis: a conservative approach. J Oral Maxillofac Surg 1991;49:788-91.

8. Santos CMC, Pimenta CAM, Nobre MRC. The PICO strategy for the research question construction and evidence search. Rev Latino - am Enfermagem 2007 maio-junho;15(3):508-11.

9. Kumar A, Bagewadi A, Keluskar V et al. Efficacy of lycopene in the management of oral submucous fibrosis. Oral Surg Oral Med Oral Pathol Oral Radiol Endod 2007;103:207-13.

10. Rao PK et al. Efficacy of Alpha Lipoic Acid in the management of Oral Submucous Fibrosis. $J$ of cancer research and therapeutics 2010;4:508-510.

11. Karemore TV, Motwani M et al. Evaluation of the effect of newer antioxidant Lycopene in the treatment of Oral submucous fibrosis. Indian Journal of Dental research 2012;23:524-28.

12. Sudarshan R, Annigeri RG, Sree Vijayabala G et al. Aloevera in the treatment for oral submucous fibrosis- a preliminary study. J Oral Pathol Med 2012;41:755-61.

13. Shetty $\mathrm{P}$, Shenai $\mathrm{P}$, Chatra L et al. Efficacy of spirulina as an antioxidant adjuvant to corticosteroid injection in management of oral submucous fibrosis. Indian J Dent Res 2013;24:347-50.

14. Alam S, Ali I, Giri KY et al. Efficacy of aloevera gel as an adjuvant treatment of oral submucous fibrosis. Oral Surg Oral Med Oral Pathol Oral Radiol 2013;116:717-24.

15. Selvam NS, Dayanand AA et al. Lycopene In The Management Of Oral Submucous Fibrosis. Asian J Pharm Clin Res 2013;6:58-61.

16. Patil S, Halgatti V, Maheshwari S et al. Comparative efficacy of oxitard and aloevera in OSMF. J Clin Exp Dent 2014;6:265-70.

17. Patil S, Al-Zarea BK, Maheshwari S et al. Comparative evaluation of natural antioxidants spirulina and aloevera for the treatment of oral submucous fibrosis. Journal of oral biology and craniofacial research 2015:11-15.

18. Melis M, Giosia MD, Zawawi KH et al. Low Level Laser Therapy for the Treatment of Temporomandibular Disorders: A Systematic Review of the Literature. The Journal Of Craniomandibular Practice 2012;30:1-9. 